\title{
CALIFORNIA, A NEW GENUS OF GERANIACEAE ENDEMIC TO THE SOUTHWEST OF NORTH AMERICA
}

\author{
by \\ JUAN JOSÉ ALDASORO', CARMEN NAVARRO', PABLO VARGAS', \\ LLORENÇ SÁEZ' \& CARLOS AEDO' \\ ' Real Jardín Botánico, CSIC. Plaza de Murillo, 2. E-28014 Madrid \\ ${ }^{2}$ Departamento de Biología Vegetal II, Facultad de Farmacia, Universidad Complutense. E-28040 Madrid \\ ${ }^{3}$ Departamento de Botánica, Facultad de Biología, Universidad Autónoma de Bellaterra. E-08193 Barcelona
}

\begin{abstract}
Resumen
Aldasoro, J.J., C. NAVARRo, P. VARGas, Ll. Sáez \& C. Aedo (2002). California, un nuevo género de Geraniaceae endémico del sudoeste de Norteamérica. Anales Jard. Bot. Madrid 59(2): 209-216 (en inglés).

Los datos morfológicos permiten distinguir, a nivel de género, Erodium macrophyllum Hook. \& Arn. de las especies incluidas en Erodium y Monsonia (Geraniaceae). También los datos obtenidos de la secuencia de ADN cloroplástico ( $t r n L-F)$ apoyan estas diferencias. Por lo tanto, proponemos un nuevo género monotípico, California Aldas., C. Navarro, P. Vargas, Ll. Sáez \& Aedo, para que queden mejor reflejadas las relaciones filogenéticas en la clasificación de las Geraniaceae. Incluimos una diagnosis, ilustraciones, análisis comparativos de los caracteres diferenciales y una clave de generos de Geraniaceae. Se propone una nueva combinación: California macrophylla (Hook. \& Am.) Aldas., C. Navarro, P. Vargas, LI. Sáez \& Aedo, comb. nov. [basión.: Erodium macrophyllum Hook. \& Am.]; y se designan dos lectótipos.

Palabras clave: taxonomía, morfología, Geraniaceae, Erodium, Monsonia, nuevo género, Norteamérica.
\end{abstract}

\begin{abstract}
AldDASORo, J.J., C. NAVARRo, P. VARGAS, Ll. Sáez \& C. Aedo (2002). California, a new genus of Geraniaceae endemic to the southwest of North America. Anales Jard. Bot. Madrid 59(2): 209-216.

Morphological data provide evidence for the separation of Erodium macrophyllum Hook. \& Arn. in a new genus, different from either Erodium and Monsonia (Geraniaceae). Also cpDNA sequence data (trmL-F) support this view. Thus, we propose the recognition of a new monotypic genus, Califormia Aldas., C. Navarro, P. Vargas, LI. Sáez \& Aedo, to better reflect phylogenetic relationships in Geraniaceae. We provide diagnosis, illustrations, comparative analysis of distinctive characters, and a key to genera of Geraniaceae. The new combination proposed is: California macrophylla (Hook. \& Am.) Aldas., C. Navarro, P. Vargas, Ll. Sáez \& Aedo, comb. nov. [basion.: Erodium macrophyllum Hook. \& Arn.]; and two lectotypes are designed.
\end{abstract}

Key words: taxonomy, morphology, Geraniaceae, Erodium, Monsonia, new genus, North America.

\section{INTRODUCTION}

Geraniaceae is a world-wide family comprising five genera: Erodium L'Her. ex Aiton,
Geranium L., Monsonia L., Sarcocaulon (DC.) Sweet and Pelargonium L'Her. ex Aiton (Hutchinson, 1969; KNUTH, 1912). They have pentamerous flowers consisting 
of five sepals; five petals; five antipetalous nectaries (Monsonia, Sarcocaulon, Erodium and Geranium), but only one nectary in $\mathrm{Pe}$ largonium; androecia with a variable number of stamens (15 in Monsonia and Sarcocaulon, 10 in Geranium, 2-7 in Pelargonium and 5 in Erodium), and consistently a gynoecium with 5 carpels in all genera (HuTCHINSON, 1969; KNUTH, 1912). Staminodes are only present in two genera: 5 in Erodium and a variable number in Pelargonium, from 3 to 8 (STRUCK \& VAN DER WALT, 1996). Most Geraniaceae studies have emphasized the importance of the androecium in family classifications, because it displays the main reliable characters (KNUTH, 1912).

\section{Generic delmitation in the Geraniaceae}

Generic delimitation of Erodium has never seriously been questioned after it was segregated from Geranium as originally circumscribed by Linnaeus (AITON, 1789; L'HERITIER, 1792). The major difference between Erodium and Geranium is the fertile stamen number, ten forming two whorls in Geranium and five in a whorl plus a second whorl of five staminodes in Erodium. In both cases, stamens and staminodes are free. However, an exception is Geranium pusillum L., which lacks one whorl of fertile stamens (AEDo \& al., 1998). The other Geraniaceae genera (Monsonia and Sarcocaulon) have a whorl of 15 stamens fused in the base (monadelphous) or fused in five groups of three (pentadelphous), whereas Pelargonium has 2-7 monadelphous stamens. An exception is also found in Monsonia brevirostrata Knuth, which has only five fertile stamens (Aldasoro \& al., 2001). The androecium structure of Erodium could be related to that of Geranium due to a likely substitution of a whorl of fertile stamens by staminodes.

The protologue of Erodium macrophyllum Hook. \& Arn. is somewhat misleading, not allowing one to know the number of sterile and fertile stamens: "This is a true Erodium, having the five sterile stamens in the flower..." (HoOKER \& ARNOTT, 1838). Surprisingly,
Erodium macrophyllum Hook. \& Arn. has no staminodes, but has a quite distinctive staminal structure: the filaments have a widely dilatated basal portion with two lateral wing-like expansions apically rounded or almost auriculate (fig. 1c, d). The normal narrow apical part being aparently insert in the upper third of this basal structure (fig. 1d). This peculiar staminal filament has a certain resemblance to each of the five groups of stamens of $\boldsymbol{M}$. brevirostrata (ALDASORO \& al., 2001).

Characters from leaves and fruits are much more variable within the Geraniaceae and usually not used to recognize different genera, but they serve to distinguish infrageneric taxa. Some of them also support the segregation of E. macrophyllum from Erodium. On the surface of Erodium mericarps there are stout bristles which may serve to facilitate burying, adherence and dispersal (fig. 1e; figs. 2A-D). At the base, Erodium species have a nearly semicircular rim surrounding each bristle, which is formed by fusion of papillae (fig. 2D). It serves to prevent the bristle from returning and avoid unburying (EL-OQLAH, 1989; Aldasoro \& al., 2001). The only Erodium without these rims is E. macrophyllum (fig. 2C). In the Geraniaceae, similar rims are only found in some species of Monsonia (AldAsoro \& al., 2001). The mericarp apex of many species of Erodium has two pits which are frequently filled by glands. These pits are in most Erodium obliquely situated with respect to the awn (fig. 2B), whereas they are almost perpendicularly disposed in E. macrophyllum (fig. 1e; fig. 2A). Monsonia has also these two types of pits (oblique and perpendicularly placed) depending on the species (ALDASORO \& al., 2001).

Finally, E. macrophyllum leaves are also distinctive. They are rounded, with a cordate base and subpalmate veins (fig. 1a, b), while all other species of Erodium have subpinnate or pinnate veins. Monsonia has both subpalmate (or palmate) and pinnate veins, depending on the species.

As discussed above, E. macrophyllum features resemble in some cases Erodium, in 


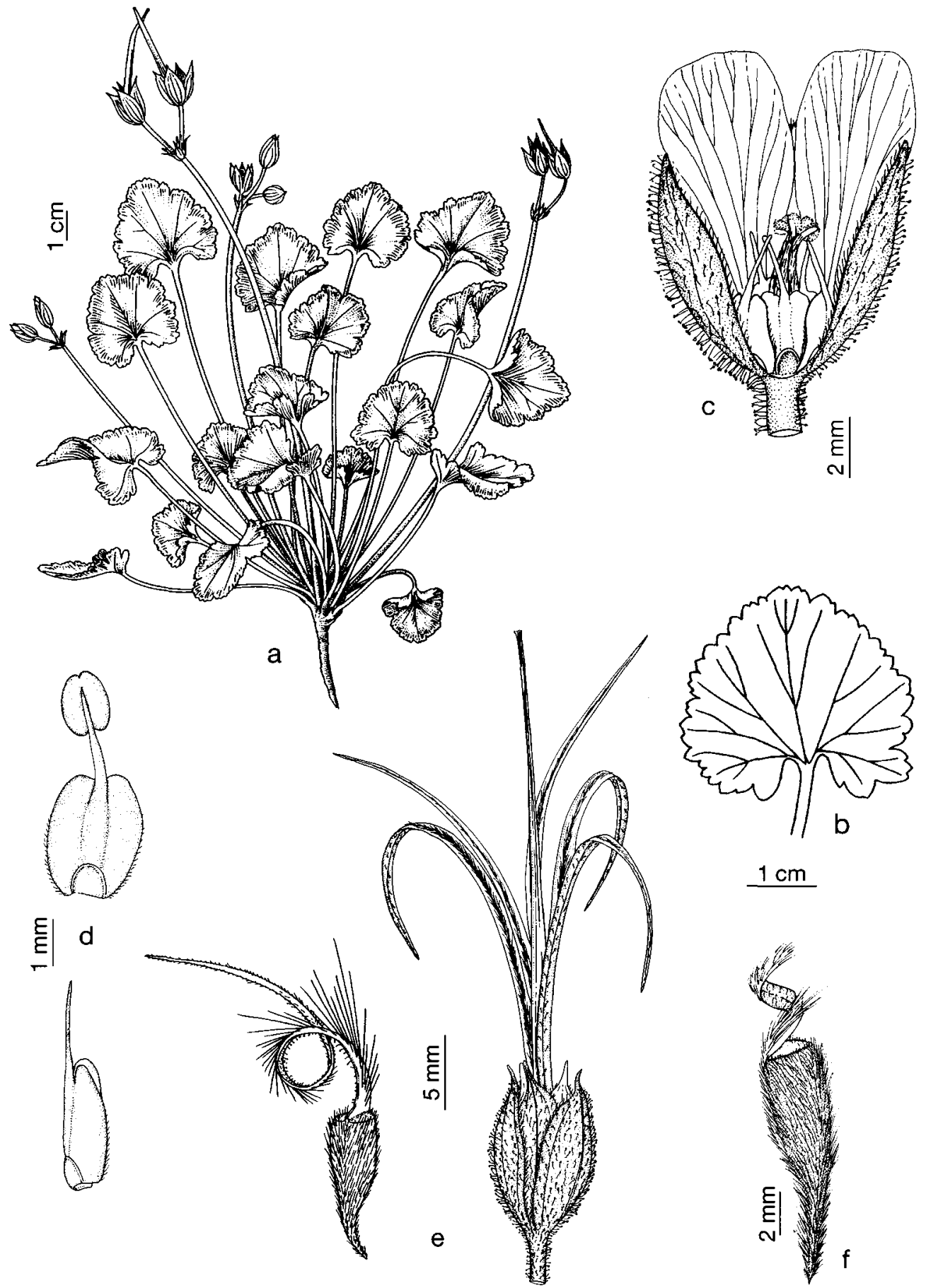

Fig. 1.-California macrophylla: a, habit; b, basal leaf; c, open flower showing androecium and gynoecium; d, stamen; e, fruit and mericarp; f, mericarp (based on Heller 783I P). [a, b by LI. Sáez; c-f by J. Castillo]. 

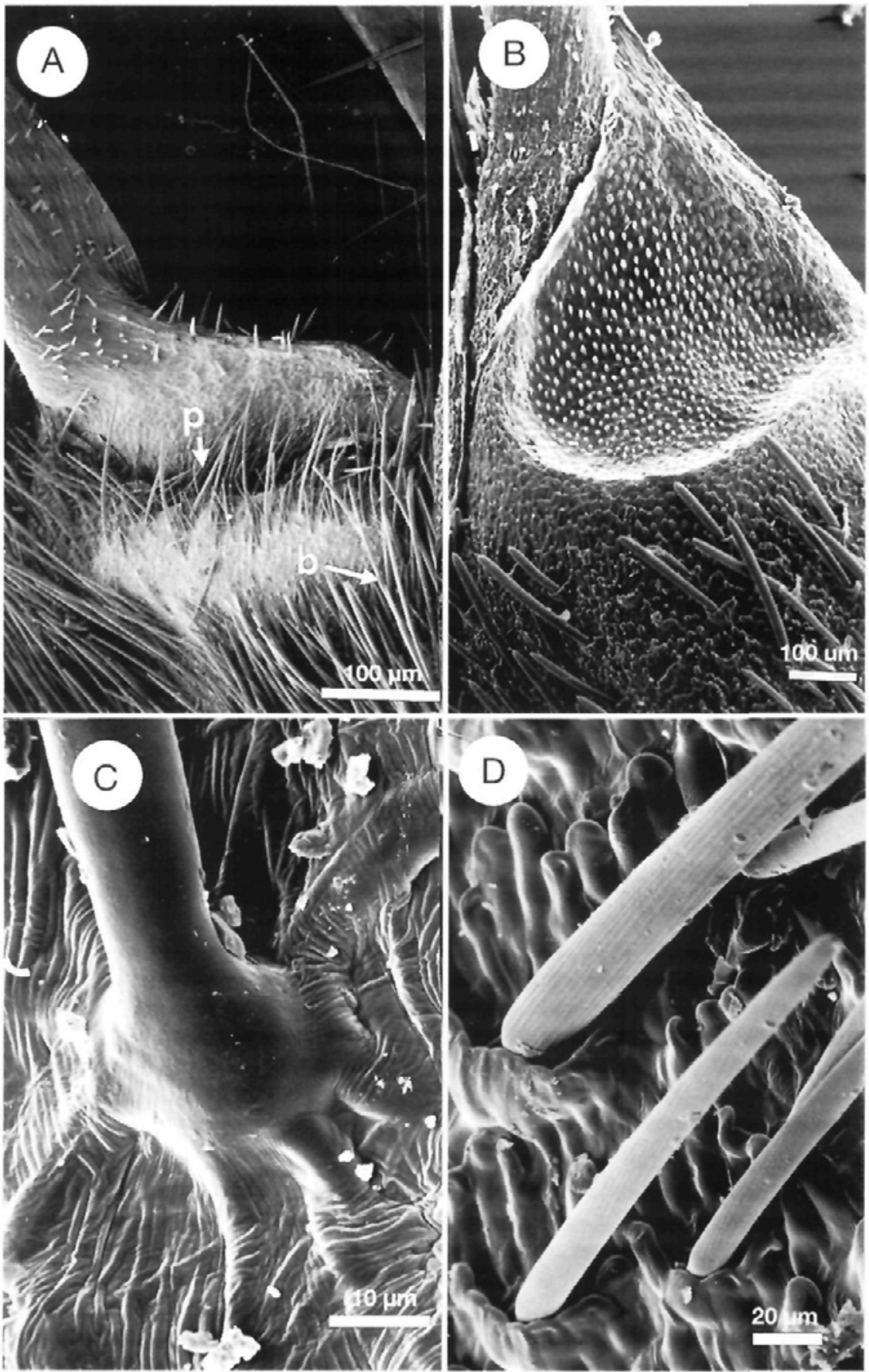

Fig. 2.-SEM micrographs of mericarps of California and Erodium: A, C. macrophylla mericarp apex (b, bristles; p, pit) (based on Heller 783 I P); B, E. laciniatum mericarp apex (based on Rigual s.n., MA 371870); C. C. macrophylla bristle base; D, E. atlanticum bristles base (based on Ball s.n., COI). 
others Monsonia. This, together with a unique androecium type (figs, 1c, d), leads us to segregate it in a different genus, especially taking into account the androecium, the most reliable diagnostic character in Geraniaceae taxonomy (KNUTH, 1912; YEO, 1990).

Moreover, a preliminary phylogeny of Geraniaceae using $t r n L-F$ sequences from representatives of the five genera plus $E$. macrophyllum allow us to hypothesize a relatively distant relationship between this species and Erodium. The two mostparsimonious trees resolve $E$. macrophyllum as sister to Erodium, even with low bootstrap support $(<50 \%)$, and indicate an ancient divergence between them.

\section{Key to GeraniaCEAE GENERA (see below for exceptions)}

1. Androecium of 15 stamens 2

- Androecium of 2-10 stamens 3

2. Plants succulent; stems covered with waxy cuticle; longest petioles persisting as spines ..... Sarcocaulon

- Plants usually not succulent; stems not covered with waxy cuticle; longest petioles not persisting as spines Monsonia

3. Flowers with only a nectary which is deeply embedded into the receptacle (rarely without nectary), generally zygomorphous; 2-7 monadelphous stamens

Pelargonium

- Flowers with five nectaries not deeply embedded into the receptacle. actinomorphous or slightly zygomorphous; 5 or 10 free stamens

4. Flowers with 10 fertile stamens ... Geranium

- Flowers with 5 fertile stamens

5. Flowers with a whorl of 5 staminodes placed between the stamens; mericarps with a semicircular rim surrounding each bristle base

Erodium

- Flowers without staminodes; mericarps without a semicircular rim surrounding each bristle base California

Some exceptions for Geranium (G. pusillum), Monsonia ( $M$. brevirostrata), Pelargonium ( $P$. incarnatum) have not been included in the above key. Preliminary phylogenies suggest that $G$. pusillum androecium (5 stamens) is a derivative state from 10 stamens in Geranium sect. Batrachioidea W.D.J. Koch (AEDo \& al., 1998); the androecium of $M$. brevirostrata (5 stamens) is a result of reduction of stamen number (ALDASORO \& al., 2001). As far as we know, there is no information on the phylogenetic position of Pelargonium incarnatum.

California Aldas., C. Navarro, P. Vargas, L1. Sáez \& Aedo, gen. nov.

Typus: California macrophylla (Hook. \& Arn.) Aldas. \& al. [Erodium macrophyllum Hook. \& Arn.]

Differt ab affini gen. Erodium staminodiis nullis, uniuscuiusque foveola versus aristam perpendiculariter disposita et mericarpiorum pilis bursicula basali carentibus.

Novum genus, ut patet, nomen trahit $e$ terris ubi habitat.

This genus is similar to Erodium, from which can be distinguished by the androecium, lack of staminodes, mericarp pit perpendicularly disposed with respect to the awn, bristle rims absent and leaves subpalmately veined.

We choose this generic epithet to honour a Floristic Province of America named California, where this genus occurs.

California macrophylla (Hook. \& Arn.) Aldas., C. Navarro, P. Vargas, Ll. Sáez \& Aedo, comb. nov.

$\equiv$ Erodium macrophyllum Hook. \& Arn., Bot. Beechey Voy.: 327 (1838), basion.

Ind. loc.: "California, Mr. Douglas"

Typus: USA. California, 1834, Douglas s.n. (lectotype, here designated, BM!; isolectotype, $\mathrm{GH}$ )

Erodium californicum Greene, Fl. Francisc.: 99 (1891); Erodium macrophyllum var. californicum (Greene) Jeps., Fl. W. Calif.: 247 (1901)

Ind. loc.: "Berkeley Hills and eastward in the Mt. Diablo Range"

Typus: USA. California, Berkeley Hills, 3 Apr. 1887, Greene s.n. (lectotype, here designated, NDG 28051; seeing colour slide!) 
Annual or biennial plant, shortly caulescent or nearly acaule. Roots short, slightly ramified. Stems 10-40 cm long, ascending, hairy, with eglandular hairs $0.3-0.5 \mathrm{~mm}$ long and glandular hairs $0.4-0.6 \mathrm{~mm}$ long, all nearly patent or retrorse, the glandular producing a reddish secretion. Leaves long petiolate, rounded or cordate, crenate-dentate, shallowly lobed (rarely deeply lobed), with eglandular hairs 0.3-0.5 mm long and glandular hairs 0.5-0.6 mm long; subpalmately nerved, with 1-2 pairs of secondary nerves; basal leaves 11-43 × 10-44 mm (ratio leaf width/leaf length : 0.9-1.1); cauline leaves 10-33 × 8-32 mm; stipules 3-4.1 mm long, oval-lanceolate, not membranous, hairy, with glandular hairs $0.4-0.6 \mathrm{~mm}$ long along the margin and on the abaxial side. Inflorescence 1-5 flowered, with peduncles arising from the rootstock; bracts 2-5, 3.2-5 x 1.3-1.6 mm, free, acuminate, with a narrow scariose margin, with eglandular hairs 0.2 $0.3 \mathrm{~mm}$ long on the abaxial side, glabrous adaxially; pedicels hairy, with eglandular hairs c. $0.2 \mathrm{~mm}$ long and glandular hairs 0.3 $0.6 \mathrm{~mm}$ long. Flowers actinomorphous, hermaphrodite. Sepals 5-7.1 $\times$ 2.3-3.2 mm, awned, acrescent (11-14 $\times$ 4.3-5.6 $\mathrm{mm}$ in fruit), awn 0.8-1.5 mm long (0.9-1.3 long in fruit); abaxial side with crowded eglandular hairs 0.2-0.3 mm long and glandular hairs 0.5$0.6 \mathrm{~mm}$ long. Petals $6.2-8 \times 2-3.2 \mathrm{~mm}$, all similar, pink or white. Stamen 5; filament 2.5$3 \mathrm{~mm}$ long, with a glabrous, slender, free part (1.6-1.8 $\times$ 0.4-0.7 mm) inserted on the upper third of a dilatate basal portion with two lateral appendage-like wings; the basal portion 2.3-2.6 × 1.3-1.4 mm, with the two lateral wings apically auriculate, sparsely ciliate; anthers $0.8-0.9 \mathrm{~mm}$ long; pollen $35-$ $50 \mathrm{~m}$ in diam., reticulate, lumen of cells $3-5 \mathrm{~m}$ in diam.; without supratectal processes, tricolpate, yellow; staminodes absent. Nectaries 5, 0.4-0.5 $\times$ 0.5-0.6 mm, oval to rounded in transversal and longitudinal sections, adnate to the base of staminal filament, color unknown. Gynoecium 4.8$5.6 \mathrm{~mm}$ long, densely hairy, with long glandular hairs; stigmas 0.8-1 mm long. Fruit a schizocarp 44-54 mm in length; columella stout; awns not plumose (with short hairs in the upper part); mericarp length $9-12 \mathrm{~mm}$ (20-25\% of fruit length); mericarp surface without papillae, with crowded bristles of variable size, without basal rims; apical pit present, perpendicularly situated respect the awn, without ridges or furrows beside, with small glands inside, which are also in the start of awn. Seed 1 per mericarp, 5-5.5 × 1.2$1.4 \mathrm{~mm}$, with elliptic longitudinal section; hilum length $2-2.4 \mathrm{~mm}$ (40-46\% of the seed length). Cotyledon leaves ovate in outline, with a cordate base.

Chromosome number. Unknown.

Illustrations. TRELEASE (1888, pl. 10 fig. 12); fig. 1.

Phenology. Collected in flower from March to the beginning of June.

Vernacular names. Large-leaved Filaree (THOMAS, 1961)

Distribution. South Oregon and California (USA), and Baja California (Mexico); also reported from Arizona and S Utah (TAYLOR, 1993: 672); fig. 3.

Habitat. Open habitat on friable clay soils; 50-1200 m.

\section{Representative specimens examined}

USA. California: Alameda Co., Altamont Pass, $37^{\circ} 44^{\prime} \mathrm{N}, 121^{\circ} 39^{\prime} \mathrm{W}, 1-\mathrm{IV}-1923$, Abrams 9946, CAS. Alameda Co., Corral Hollow, $37^{\circ} 32^{\prime} \mathrm{N}, 121^{\circ} 55^{\prime} \mathrm{W}$, 7-IV-1940, Howell 15393, CAS. Butte Co., Chico, $39^{\circ} 44^{\prime} \mathrm{N}, 121^{\circ} 51^{\prime} \mathrm{W}, 1896$, Austin 984, P. Colusa Co., Stonyford Road, $39^{\circ} 22^{\prime} \mathrm{N}, 122^{\circ} 32^{\prime} \mathrm{W}, 23-\mathrm{IV}-1926$, Ferris 6406, CAS. Contra Costa Co., Antioch, $38^{\circ} 0^{\prime} \mathrm{N}$, $121^{\circ} 48^{\prime}$ W, Brandeque s.n., CAS. Contra Costa Co., Brentwood, $37^{\circ} 55^{\prime} \mathrm{N}, 121^{\circ} 41^{\prime} \mathrm{W}, 5-\mathrm{V}-1892$, Eastwood s.n., MO. Contra Costa Co., near Kirker Pass, 37 $57^{\circ} \mathrm{N}$, $121^{\circ} 55^{\prime} \mathrm{W}, 10-\mathrm{V}-1862$, Brewer 1067, K. Fresno Co., $14 \mathrm{mi}$ W of Coalinga, $36^{\circ} 8^{\prime} \mathrm{N}, 120^{\circ} 21^{\prime} \mathrm{W}, 10-\mathrm{IV}-1949$, Wiggins 12040, CAS. Kern Co., $0.25 \mathrm{mi}$ E of White River on Greenville road, $35^{\circ} 8^{\circ} \mathrm{N}, 118^{\circ} 23^{\prime} \mathrm{W}, 30$-III-1939, Ferris 9727, CAS. Kern Co., Adobe Canyon, $35^{\circ} 31^{\prime}$, $11^{\circ} 55^{\prime}$ W, 26-IV-1965, Twisselmann 10603, CAS. Kern Co., Diablo Range, Cottonwood Canyon, 35 $50^{\prime} \mathrm{N}$, $118^{\circ} 42^{\prime} \mathrm{W}, 17-\mathrm{IV}-1935$, Wolf 6441, CAS. Kern Co., Drake Ridge, $35^{\circ} 8^{\prime} \mathrm{N}, 118^{\circ} 23^{\prime} \mathrm{W}, 28-\mathrm{IV}-1952$, Twisselmann 422, CAS. Kern Co., Tehachapi, 357'N, $118^{\circ} 26^{\prime} \mathrm{W}, 5-\mathrm{V}-1905$, Heller 7831, P, MO; ibídem, 13V-1913, Eastwood 3251, CAS. Kern Co., Temblor Summit, 35'3'N, $119^{\circ} 29^{\prime} \mathrm{W}, 20-\mathrm{IV}-1966$, Twisselmann 11974, CAS. Kings Co., Reef Ridge Canyon, 35 $57^{\prime} \mathrm{N}$, 120 13'W, 2-IV-1955, Twisselmann 1792, CAS. Kings Co., Tar Canyon, hills west of Avenal, $36^{\circ} 1^{\prime} \mathrm{N}, 120^{\circ} 8^{\prime} \mathrm{W}$, 23-III-1940, Hoover 4280, K. Los Angeles Co., Oso Canyon, 34 $48^{\prime} \mathrm{N}, 18^{\circ} 43^{\prime} \mathrm{W}, 18-\mathrm{IV}-1962$, Twisselmann 


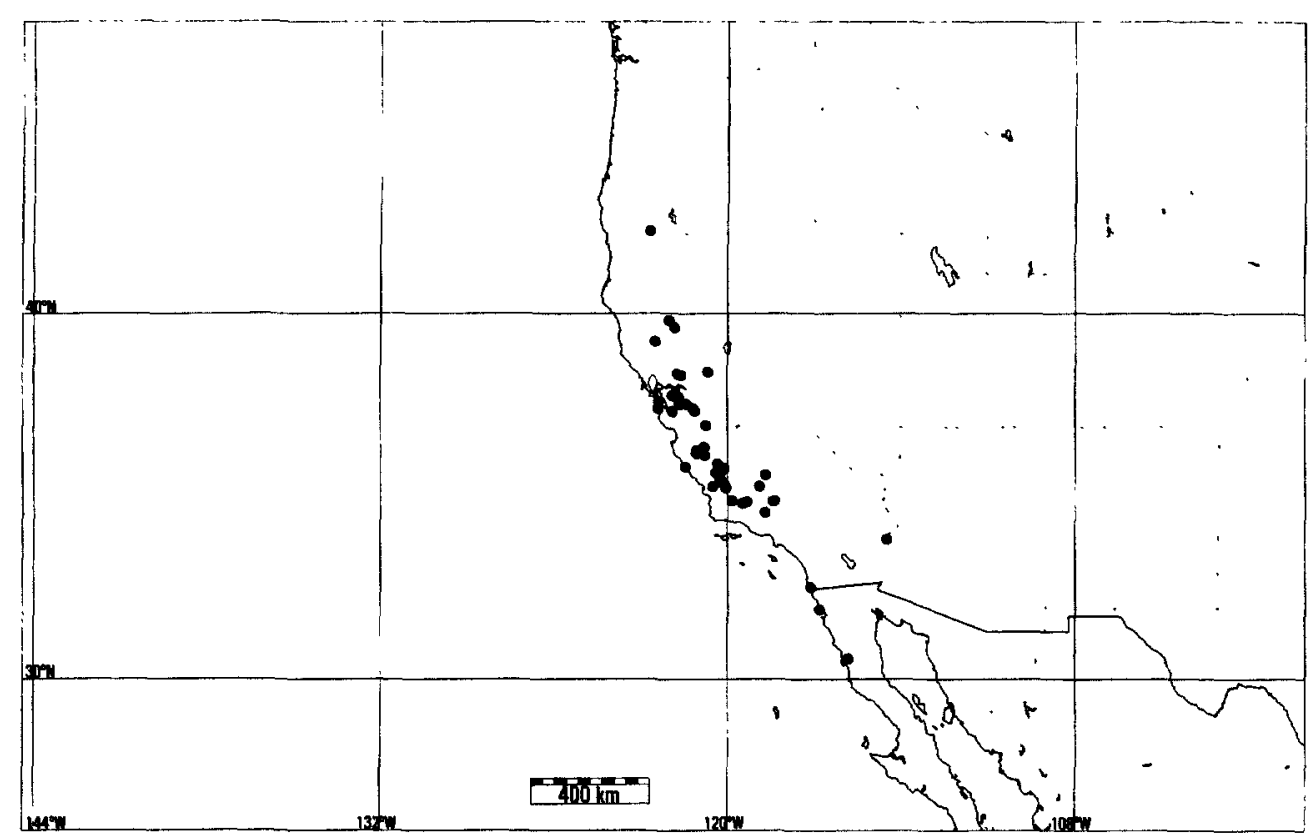

Fig. 3.-Distribution of California macrophylla based on examined specimens.

6959, CAS. Merced Co.. $37^{\circ} 10^{\prime} \mathrm{N}, 120^{\circ} 45^{\prime} \mathrm{W}, 23-\mathrm{IV}$. 1915, Eastwood 4428, CAS. Monterey Co., Parkfield, $35^{\circ} 53^{\prime} \mathrm{N}, 120^{\circ} 25^{\prime} \mathrm{W}, 2-\mathrm{V}-1937$, Eastwood \& Howell 4207, CAS. Monterey Co., Santa Lucía Mts., 36³'N, $121^{\circ} 28^{\prime} \mathrm{W}, 24-\mathrm{V}-1948$, Linsdale s.n., CAS. Riverside Co., Alice Mine, $34^{\circ} 3^{\prime} \mathrm{N}, 114^{\circ} 30^{\prime} \mathrm{W}, \mathrm{V}-1807$, Holl s.n., CAS. Sacramento Co., Sacramento valley, $38^{\circ} 35^{\prime} \mathrm{N}$, $120^{\circ} 40^{\prime} \mathrm{W}, 1848$, Hartvey 1675, K, W. San Benito Co., $1 \mathrm{mi}$ from Peralta School near Idria, $36^{\circ} 25^{\prime} \mathrm{N}, 121^{\circ} 5^{\prime} \mathrm{W}$, 28-IV-1940, Wiggins \& Ferris 9391, CAS. San Benito Co., 11 mi from Hernandez, $36^{\circ} 22^{\prime} \mathrm{N}, 120^{\circ} 48^{\prime} \mathrm{W}, 29$-III1931, Howell 6026, CAS. San Benito Co., $2.6 \mathrm{mi} \mathrm{N}$ of Idria, $36^{\circ} 25^{\prime} \mathrm{N}, 121^{\circ} 5^{\prime} \mathrm{W}, 13-\mathrm{IV}-1941$, Wiggins \& al. 41, CAS. San Benito Co, near San Benito, $36^{\circ} 30^{\prime} \mathrm{N}$, $121^{\circ} 4^{\prime} \mathrm{W}, 22-I V-1933$, Howell 11084, CAS. San Benito Co., Panoche, $36^{\circ} 35^{\prime}$ N, $120^{\circ} 49^{\prime}$ W, 3-V-1937, Eastwood \& Howell 4286, CAS. San Diego Co., S of San Diego, $32^{\circ} 43^{\prime}$ N. $117^{\circ} 8^{\prime} \mathrm{W}, 1875$, Palmer 5214, MO; ibídem, V1884, Cleveland s.n., CAS; ibídem, 5-V-1905, Cleveland s.n., MO. San Francisco Co., near San Francisco, $37^{\circ} 47^{\prime} \mathrm{N}, 122^{\circ} 24^{\prime} \mathrm{W}, 1868$, Kellog \& W. Harford 116, MO. San Joaquín Co., Hospital Canyon, $37^{\circ} 37^{\prime} \mathrm{N}$, $121^{\circ} 12^{\prime}$ W, 18-IV-1938, Eastwood \& Howell 5089, CAS. San Joaquín Co., Tracy, 37 $44^{\prime}$ N, $121^{\circ} 25^{\prime}$ W, IV-1938, Bellne s.n., CAS. San Luis Obispo Co., $14 \mathrm{mi}$ E of Creston, $35^{\circ} 31^{\prime} \mathrm{N}, 120^{\circ} 31^{\prime} \mathrm{W}, 21-\mathrm{IV}-1949$, Hoover 7623, CAS. San Luis Obispo Co., Bitterwater Creek, $35^{\circ} 6^{\prime} \mathrm{N}, 19^{\circ} 20^{\prime} \mathrm{W}, 23-11 \mathrm{I}-1965$, Twisselmann 10496 , CAS. San Luis Obispo Co., Choice Valley, $35^{\circ} 36^{\prime} \mathrm{N}$, 120'9'W, 19-IV-1935, Wiggins 7959, CAS. San Luis Obispo Co., Cholame, $35^{\circ} 43^{\prime} \mathrm{N}, 120^{\circ} 17^{\prime} \mathrm{W}, 25-\mathrm{III}-1935$. Eastwood \& Howell 2027, CAS. San Luis Obispo Co.,
Creston Road, $35^{\circ} 31^{\prime} \mathrm{N}, 120^{\circ} 31^{\prime} \mathrm{W}, 6-\mathrm{V}-1952$, Hoover 8152, CAS. San Luis Obispo Co., Painted Rock, 35 $8^{\prime} \mathrm{N}$, $119^{\circ} 51^{\prime}$ W, 21-IV-1941, Ripley \& Barneby 3283, CAS. San Luis Obispo Co., Pinole Springs, $35^{\circ} 29^{\prime} \mathrm{N}, 120^{\circ} 4^{\prime} \mathrm{W}$, 7-V-1952, McMillan 117, CAS. San Luis Obispo Co., San Joaquín Valley. 26-IV-1955, Twisselmann 1894, CAS. San Luis Obispo Co., Twisselmann Ranch, $35^{\circ} 39^{\prime} \mathrm{N}, 120^{\circ} 12^{\prime} \mathrm{W}, 16-\mathrm{IV}-1954$. Twisselmann 1066, CAS. San Mateo Co., Pescadero, $37^{\circ} 36^{\prime} N, 122^{\circ} 25^{\prime} \mathrm{W}, 7-$ IV-1896, Hudley s.n., CAS. Solano Co., Elmira, $38^{\circ} 30^{\prime} \mathrm{N}, 121^{\circ} 36^{\prime} \mathrm{W}, 4-\mathrm{V}-1886$, Wallace s.n., CAS. Sonoma Co., Petaluma, $38^{\circ} 15^{\prime} \mathrm{N}, 122^{\circ} 35^{\prime} \mathrm{W}$. V-1880, Congdon s.n., CAS. Stanislaus Co., Arectimba Creek, $37^{\circ} 33^{\prime} \mathrm{N}, 121^{\circ} 8^{\prime} \mathrm{W}, 24-\mathrm{IV}-1937$, Ewan 10220, CAS. Stanislaus Co., hills west of camp 76, 37 $33^{\prime} \mathrm{N}, 121^{\circ} 8^{\prime} \mathrm{W}$, 16-VI-1862, Brewer 1280, K. Tehama Co., Vina, $39^{\circ} 55^{\prime}$ N, $122^{\circ} 3^{\prime}$ W. 29-IV-1917, Srobe s.n., CAS. Yolo Co., Moon Ranch $7 \mathrm{mi}$ W of Davis, $38^{\circ} 32^{\prime} \mathrm{N}, 121^{\circ} 44^{\prime} \mathrm{W}$, 12-V-1955. Crampton 2773, CAS. OREGON: Jackson Co., near Ashland, $42^{\circ} 11^{\prime} \mathrm{N}, 122^{\circ} 42^{\prime} \mathrm{W}, 15-\mathrm{IV}-1889$, Howell s.n., MO.

Mexico. Baja California: $20 \mathrm{~m}$ SW of Tia Juana, near Rancho Cuevas, 32 ${ }^{\circ} 5^{\prime} \mathrm{N}, 116^{\circ} 50^{\prime} \mathrm{W}, 3-\mathrm{IV}-1931$, Wiggins 5123, CAS. Arroyo de la Escopeta, $30^{\circ} 42^{\prime} \mathrm{N}$, $115^{\circ} 49^{\prime}$ W, 3-VI-1975, Moran 22375, CAS.

\section{ACKNOWLEDGEMENTS}

The authors thank M. Laínz for rendering the Latin diagnosis, and B. Baldwin and B. Bartolomew 
for providing material suitable for DNA analysis. We also thank the curators of BM, CAS, F, K, MO, NDG, $P, W$ for the loan of specimens used in this study. This work was partly financed by the Spanish Dirección General de Investigación Científica y Técnica (DGICYT) through the research projects PB96-0849, and REN2000-0818.

\section{REFERENCES}

Aedo, C., J.J. Aldasoro \& C. Navarro (1998). Taxonomic revision of Geranium L., sections Divaricata Rouy and Batrachioidea W.D.J. Koch (Geraniaceae). Ann. Missouri Bot. Gard. 85: 594-630. ArTon, W. (1789). Hortus Kewensis, vol. 2. London.

Aldasoro, J.J., C. Navarro, P. Vargas, \& C. Afdo (2001). Anatomy, Morphology, and Cladistic Analysis of Monsonia L. (Geraniaceae). Anales Jard. Bot. Madrid 58: 594-630.

EL-OQLAH, E. (1989). A revision of the genus Erodium L'Héritier in the Middle East. Feddes Repert. 100: 3-4.

HOOKER, W.J. \& G. ARNOTT (1838). The Botany of Captain Beechey's Voyage. Henry G. Bohn. London.
Hutchinson, J. (1969). Evolution and phylogeny of flowering plants. Academic Press, London.

KNUTH, R. (1912). Geraniaceae. In: A. Engler (ed.), Das Pflanzenreich. IV.129 (Heft 53). Leizpig.

L'HérITIER, C.L. (1792). Geraniologia. Paris, London, Vienna \& Strasbourg.

STRUCK, M. \& J.J.A. VAN DER WALT (1996). Floral structure and pollination in Pelargonium. The Biodiversity of African Plants. Kluwer Academic Publishers. Netherlands.

TAYLOR, M.S. (1993). Erodium. In: J.C. Hickman (ed.), The Jepson Manual. Univ. of California Press, Berkeley, Los Angeles, London.

THOMAS, J.H. (1961). Flora of the Santa Cruz Mountains of California. Stanford Univ. Press. Stanford, California.

Trelease, W. (1888). A study of North American Geraniaceae. Mem. Boston Soc. Nat. Hist. 4: 71-103, pl. 9-12.

YEo, P. (1990). The classification of Geraniaceae. In: P. Vorster (ed.), Proceedings of the international Geraniaceae symposium. Stellenbosch.

Editado por Ginés López González Aceptado para publicación: 10-XI-2001 